\title{
Penile testis ectopia: a rare urogenital condition
}

\author{
Renato Lains Mota, Filipe Alpoim Lopes, Tiago Rodrigues, Nidia Rolim
}

Department of Urology, Centro Hospitalar de Lisboa Ocidental, EPE, Lisbon, Portugal

\section{Correspondence to}

Renato Lains Mota,

renato.lains.mota@gmail.com
To cite: Mota RL, Lopes FA, Rodrigues T, et al. BMJ Case Rep Published online:

[please include Day Month Yearl doi:10.1136/bcr-2012008283

\section{DESCRIPTION}

Ectopic testis is thought to result from an abnormality of terminal testicular descent in which the testis initially descends normally through the external inguinal ring but then, due to some mechanical failure, comes to rest at a location outside the normal pathway of descent. ${ }^{1}{ }^{2}$ Although several theories support that ectopia relates to some gubernaculum development abnormality, there are still no proven studies that identify the biochemical cause of it. ${ }^{1}$

An ectopic testis may be located in the superficial inguinal pouch of Denis Browne, perineum and penis or lateral to the scrotum, pubic region, thigh or contralateral scrotum. ${ }^{1}$

A 14-year-old boy from Sao Tome e Principe presented in the urology department, visiting for a congenital penile mass that grew in the last year. There was no pain associated. On genital physical examination, there were signs of puberty and an oval mass was seen in the dorsal surface of the penile shaft. The right hemiscrotum had no testicle (figure 1).

It was assumed a right testis ectopia in penile shaft and was proposed to carry out a surgical reconstruction to replace the penile right testis in the hemiscrotum. An inguinal right incision was performed (figure 2) to expose the cord and orquidopexia (figure 3).

This is a rare case with only a few cases reported in the literature. All the reports declare the same surgical approach so that it can evaluate the absence of hernia and, after mobilisation of the testis and its cord, replacement to the correspondent scrotal side. ${ }^{12}$

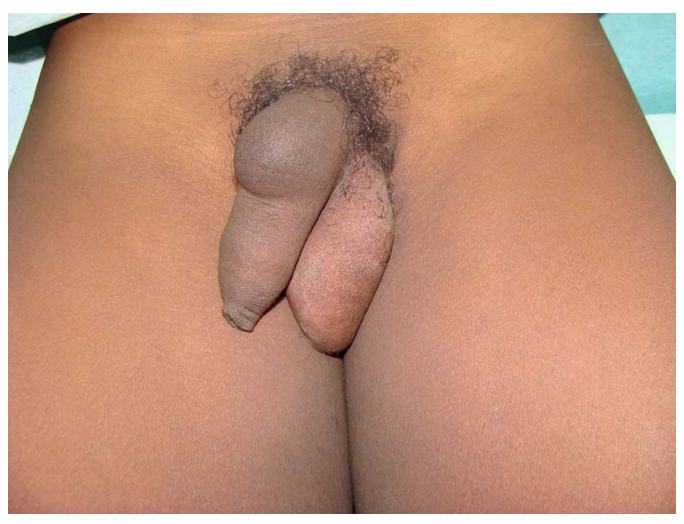

Figure 1 Preoperative evaluation.

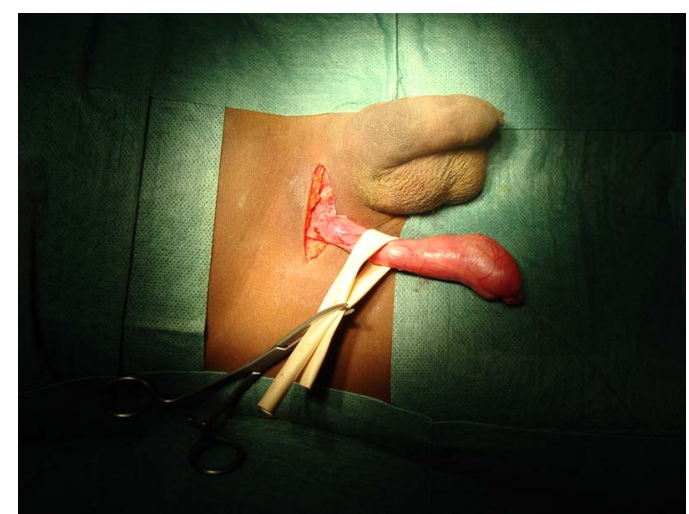

Figure 2 Inguinal exploration and cord exposition to evaluate its length.

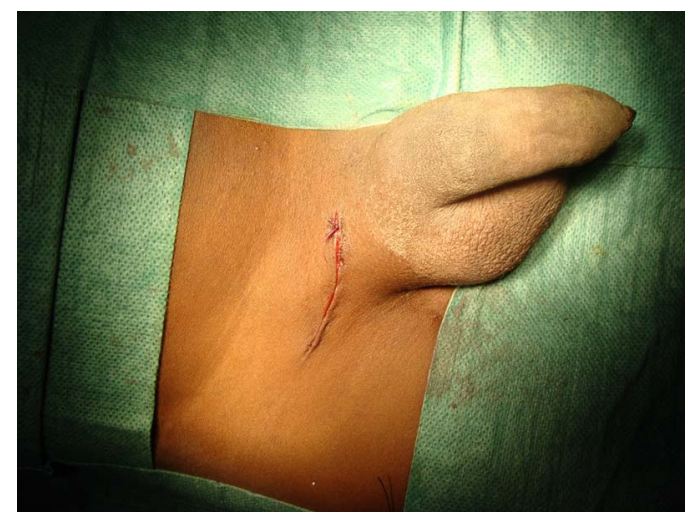

Figure 3 Final observation after orchidopexy in the homolateral scrotum.

\section{Learning points}

- Penile testicular ectopia is a rare genital malformation associated with a change in the implementation of the gubernaculum after the passage in the inguinal canal.

- The surgical inguinal resolution allows the preservation of the testicle with good aesthetic results.

Acknowledgements Thanks to Dr Pedro Monteiro and Dr Hélder Monteiro for their collaboration in the clinical management of the case. 
Competing interests None.

Patient consent Obtained.

Provenance and peer review Not commissioned; externally peer reviewed.

\section{REFERENCES}

1 Pugach JL, Steinhardt GF. Evaluation and management of ectopic penile testis. Urol 2002:59:137.

2 Concodora JA, Evans RA, Smith MJ. Ectopic penile testis. Urol 1976;8:263-4.

Copyright 2013 BMJ Publishing Group. All rights reserved. For permission to reuse any of this content visit

http://group.bmi.com/group/rights-licensing/permissions.

BMJ Case Report Fellows may re-use this article for personal use and teaching without any further permission.

Become a Fellow of BMJ Case Reports today and you can:

- Submit as many cases as you like

- Enjoy fast sympathetic peer review and rapid publication of accepted articles

- Access all the published articles

- Re-use any of the published material for personal use and teaching without further permission

For information on Institutional Fellowships contact consortiasales@bmjgroup.com

Visit casereports.bmj.com for more articles like this and to become a Fellow 